\title{
Assessment of the entry of the Moscow Exchange into the capital of the Kazakhstan Stock Exchange in the context of integration
}

\author{
Lyailya A. Baibulekova ${ }^{1}$, Nazym K. Zaitenova ${ }^{1 *}$, Gulmira S. Sugirova ${ }^{2}$ \\ ${ }^{1}$ K. Sagadiev University of International Business, 8A Abaya Ave., 050010, Almaty, Kazakhstan \\ ${ }^{2}$ Al-Farabi Kazakh National university, 71 al-Farabi Ave., 050040, Almaty, Kazakhstan
}

\begin{abstract}
This article an attempt was made to assess the entry of the Moscow Exchange in the capital of the Kazakhstan Stock Exchange as one of the alternative ways to enhance the country rankings of Kazakhstan and entering developing countries. For the study, methods of cognition, economic analysis and comparisons, study of documents, etc. Materials were used. An institutional approach was also applied, and in assessing country risk were used by the methods of widely well-known international rating agencies MSCI and FTSE Group. The scientific and information base was scientific publications of foreign and domestic scientists, as well as regulatory acts of Kazakhstan. Based on monitoring and analyzing existing country risk calculation methodologies, the MSCI indices, according to which the Republic of Kazakhstan in 2017 are chosen as banchmark. Awarded the «Frontier Market» rating. The key goals of cooperation and the entry of the Moscow Exchange in the capital of the Kazakhstan Stock Exchange were revealed. A qualitative and quantitative analysis of the Investor Base of the Moscow Exchange for the attractiveness of assets as a key determinant of its liquidity is carried out. It was concluded that according to the current market position, the influx of even $1 \%$ of the average monthly trading volume of retail investors on MOEX (20 billion tenge) on the KASE stock exchange market will lead to an increase in the volume of trading in KASE individuals four times.
\end{abstract}

Keywords: economy, stock market, stock exchange, share liquidity, capitalization, strategy and practice, investor base, EAEU, integration

For citation: Baibulekova, L.A., Zaitenova, N.K., \& Sugirova, G.S. (2021). Assessment of the entry of the Moscow Exchange into the capital of the Kazakhstan Stock Exchange in the context of integration. Economics: the Strategy and Practice, 16(4), 34-45, https://doi.org/10.51176/1997-9967-2021-4 -34-45

* Corresponding author: Zaitenova N.K. - PhD, K. Sagadiev University of International Business, 8A Abaya Ave., 050010, Almaty, Kazakhstan, 87759532345, e-mail: nazym beisebaeva@mail.ru

Conflict of interests: the authors declare that there is no conflict of interest

Financial support: The study was not sponsored (own resources).

The article received: 25.06 .2021

The article approved for publication: 21.07. 2021

Date of publication: 30.12 .2021 


\title{
Мәскеу биржасының интеграция жағдайында Қазақстан қор биржасының капиталына кіруін бағалау
}

\author{
Байбөлекова Л.Ә. ${ }^{1}$, Зайтенова Н.К. ${ }^{1 *}$, Сүгірова Г.С. ${ }^{2}$ \\ ${ }^{1}$ K. Савадиев атындавы Халықаралық бизнес университеті, Абай даңңв., 8А, 050010, Алматы, \\ Қазақсстан Республикасы \\ 2 әл-Фараби атындавы Қазақ Ұлттық университеті, әл-Фараби даңъ., 71, 050040, Алматы, \\ Қазақ̧стан Республикасы
}

\begin{abstract}
Түйін
Бұл мақалада Мәскеу биржасының Қазақстан қор биржасының капиталына Қазақстанның елдік рейтингін көтерудің және дамушы елдерге қатарына кірудің балама жолдарының бірі ретінде баға беруге әрекет жасалды. Зерттеу үшін таным әдістері, экономикалық талдау және салыстыру, құжаттарды зерттеу және т.б. материалдар қолданылды. Сондай-ақ институционалдық тәсіл қолданылды, ал елдік тәуекелді бағалау кезінде кеңінен танымал MSCI және FTSE Group халықаралық рейтинг агенттіктерінің әдістемелері пайдаланылды. Шетелдік және отандық ғалымдардың ғылыми жарияланымдары, сондай-ақ Қазақстанның Нормативтік-құқықтық актілері ғылыми және ақпараттық база болып табылды. Деректер көзі Қазақстан қор биржасының, Мәскеу биржасының ресми ақпараты болды. Елдік тәуекелді есептеудің қолданыстағы әдіснамаларын мониторингілеу және талдау негізінде бэнчмарк ретінде ең танымал болып таңдалды және елдік рейтингті айқындау MSCI индекстері болып табылады, оған сәйкес 2017 жылы Қазақстан Республикасына. «Frontier market” peйтингі берілді. Ынтымақтастықтың және Мәскеу биржасының Қазақстан қор биржасының капиталына кіруінің негізгі мақсаттары анықталды. Бұл ынтымақтастық мақсаттары инвесторларға, кәсіби инвесторларға және тұтастай алғанда бүкіл ел экономикасына пайда әкеледі. Мәскеу биржасының инвестициялық базасына оның өтімділігінің негізгі детерминанты ретінде активтердің тартымдылығына сапалы және сандық талдау жүргізілді. Нарықтың ағымдағы жағдайы бойынша бөлшек инвесторлардың MOEX-тегі орташа айлық сауда көлемінің 1\%-ы (20 млрд. теңге). Биржаның биржалық нарығына KASE жеке тұлғаларының сауда-саттық көлемінің төрт есе артуына алып келеді. Акциялар өтімділігі өсуінің оң әсеріне баға берілді алынған нәтижелерді қолдану саласы қазақстандық қор нарығы болып табылады.
\end{abstract}

Түйін сөздер: экономика, қор нарығы, қор биржасы, акциялардың өтімділігі, капиталдандыру, стратегия және тәжірибе, инвесторлық база, ЕАЭО, интеграция

Дәйексөз алу үшін: Байбөлекова Л.Ә., Зайтенова Н.К., Сүгірова Г.С. (2021). Мәскеу биржасының интеграция жағдайында Қазақстан қор биржасының капиталына кіруін бағалау. Экономика: стратегия және практика, 16(4), 34-45, https://doi.org/10.51176/1997-9967-2021-4 -34-45

* Хат-хабаршы авторы: Зайтенова Н.К. - PhD, К. Сағадиев атындағы Халықаралық бизнес университеті, Абай даңғ., 8А, 050010, Алматы қ., Қазақстан, 87759532345, e-mail: nazym beisebaeva@mail.ru

Мүдделер қақтығысы: авторлар мүдделер қақтығысының жоқтығын мәлімдейді.

Қаржыландыру. Зерттеу демеушілік қолдау көрсеткен жоқ (меншікті ресурстар).

Мақала редакцияға түсті: 25.06 .2021

Жариялау туралы шешім қабылданды: 21.07 .2021

Жарияланды: 30.12 .2021 


\title{
Оценка вхождения Московской биржи в капитал Казахстанской фондовой биржи в условиях интеграции
}

\author{
Байбулекова Л.А. ${ }^{1}$, Зайтенова Н.К. ${ }^{1 *}$, Сугирова Г.С. ${ }^{2}$ \\ ${ }^{l}$ Университет международного бизнеса имени К. Сагадиева, пр. Абая 8а, 050010, \\ Алиаты, Казахстан \\ ${ }^{2}$ Казахский национальный университет им. аль-Фараби, пр. аль-Фараби, 71, 050040, \\ Алматы, Казахстан
}

\begin{abstract}
Аннотация
В данной статье произведена попытка дать оценку вхождения Московской биржи в капитал Казахстанской фондовой биржи как одного из альтернативных путей повышения странового рейтинга Казахстана и вхождения в развивающиеся страны. Для проведения исследования использовались методы познания, экономического анализа и сравнения, исследование документов и пр. материалов. Также применялся институциональный подход, а при оценке странового риска использовались методики широко известных международных рейтинговых агентств MSCI и FTSE Group. Научной и информационной базой явились научные публикации зарубежных и отечественных ученых, а также нормативно-правовые акты Казахстана. Источниками данных послужили официальная информация Казахстанской фондовой биржи, Московской биржи. На основе мониторинга и анализа существующих методологий рассчета странового риска выбран самый популярный в качестве бэнчмарка и определения странового рейтинга являются индексы MSCI, согласно которому в 2017 году Республике Казахстан. присвоен рейтинг «Frontier market». Выявлены ключевые цели сотрудничества и вхождения Московской биржи в капитал Казахстанской фондовой биржи. Данные цели сотрудничества выгоды инвесторам, профессиональным инветорам и, в целом, всей экономике страны. Проведен качественный и количественный анализ инвесторской базы Московской биржи на предмет привлекательности активов как ключевого детерминанта его ликвидности. Сделан вывод, что по текущему положению рынка, приток даже $1 \%$ от среднемесячного объема торгов розничных инвесторов на MOEX (20 млрд. тенге) на биржевой рынок KASE приведет к увеличению объема торгов физических лиц KASE в четыре раза. Дана оценка положительного влияния роста ликвидности акций Областью применения полученных результатов является казахстанский фондовый рынок.
\end{abstract}

Ключевые слова: экономика, фондовый рынок, фондовая биржа, ликвидность акции, капитализация, стратегия и практика, инвесторская база, ЕАЭС, интеграция

Для цитирования: Байбулекова Л.А., Зайтенова Н.К., Сугирова Г.С. (2021). Оценка вхождения Московской биржи в капитал Казахстанской фондовой биржи в условиях интеграции. Экономика: стратегия и практика, 16(4), 34-45, https://doi.org/10.51176/1997-9967-2021-4-34-45

* Корреспондирующий автор: Зайтенова Н.К. - PhD, Университет международного бизнеса им. К. Сагадиева, пр. Абая 8a, 050010, Алматы, Казахстан, 87759532345, e-mail: nazym_beisebaeva@mail.ru

Конфликт интересов: авторы заявляют об отсутствии конфликта интересов.

Финансирование. Исследование не имело спонсорской поддержки (собственные ресурсы).

Статья поступила в редакцию: 25.06 .2021

Принято решение о публикации: 21.07.2021

Опубликовано: 30.12 .2021 


\section{Введение}

Фондовый рынок Республики Казахстан считается крайне спекулятивным, имеющим большую зависимость от внешних инвестиций, при этом недостаточно ликвидный и емкий [1]. А из-за страновых рисков финансовые инструменты торгуются на нем с большим дисконтом, чем такие же аналоги развитых (Developed) и развивающихся (Emerging) площадок [2].

Вопросы повышения рейтинга страны для Казахстана являются актуальными. Международные рейтинговые агентства FTSE и MSCI отнесли Казахстан к формирующимся рынкам (Frontier markets) [3-5]. Одним из альтернативных путей повышения рейтинга и включение Казахстана в развивающиеся рынки является интеграция в условиях ЕАЭС Казахстанской фондовой биржи (KASE) c Московской фондовой биржей (MOEX), которая находится в международном классификаторе рангом выше.

В октябре 2018 года было заключено соглашение между KASE и MOEX о стратегическом сотрудничестве и вхождении Московской биржи путем поэтапного приобретения (до 20\%) доли Казахстанской биржи. Результатом первого этапа (январь 2019 года) явилось приобретение MOEX $3,32 \%$ акций KASE. Сегодня эта цифра составляет $13,1 \%$ [6].

Цели сотрудничества:

1) взаимный доступ к фондовым площадкам обеих стран отечественным и российским участникам биржевой торговли;

2) снизить рыночные риски и повысить надежность инфраструктуры посредством развития института центрального контрагента;

3) создание новых биржевых инструментов, что повысит эффективность отечественного фондового рынка, управление рисками и пр. посредством использования экспертиз и торгово-клиринговой системы Московской биржи;

4) использовать опыт MOEX при проведении IPO АО «Казахстанская фондовая биржа».

Первая цель выгодна для участников фондового рынка - эмитентам и инвесторам, а значит и всей экономике Республики Казахстан. С декабря 2019 года на KASE приступила к действию новая российская торговоклиринговая система ASTS+ и, разработанный на ее основе, Центральный контрагент. Это подтверждает реализацию второй и третьей целей, которые имеют положительный эффект для профессиональных участников рынка ценных бумаг и инвесторов. Для достижения четвертой цели еще необходимо выполнения комплекса мероприятий и носит долгосрочный характер. Успешность ее выполнения станет действительно интересным инвесторам.

Цель данного исследования - дать оценку:

- потенциального притока инвесторской базы с Московской биржи для казахстанских компаний;

- положительного влияния роста ликвидности и капитализации казахстанских компаний;

- интереса акций казахстанских компаний со стороны российских инвесторов.

\section{Литературный обзор и методология}

В современных условиях существования экономики Республики Казахстан (РК) особую актуальность приобретают проблемы деятельности участников отечественного фондового рынка, а также вопросы с позиции интеграционных процессов.

Необходимо отметить, что в мировой финансовой системе ключевая роль отведена фондовому рынку благодаря процессам интеграции и глобализации. А наличие крупных игроков привело к необходимости слияния менее крупных биржевых площадок, которое естественным образом ведет к их интеграции.

На исследовательскую тему по факторам финансовой интеграции фондовых рынков существуют большое количество работ. Данные исследования отражают разные стороны интеграции фондовых площадок и их влияние друг на друга.

Так, в работе М.А. Авилкиной (2014) рассматриваются вопросы глобализации (интеграции) в рамках единого биржевого пространства Казахстана, Российской Федерации (РФ) и Белоруссии [7]. Изучены серьезные асимметрии в конкуренции и диспропорции по биржевым инструментам и капитализации фондовых рынков. Помимо проблем в законодательных ограничениях выделяются вопросы нерыночного ценообразования биржевых инструментов и низкая их ликвидность и др. Это проблемы препятствуют возможностям выхода на взаимные рынки, и, соответственно. увеличению количества и объема сделок на фондовых площадках данных стран. Актуальным является и возможность участия на биржевых площадках только профессиональных инвесторов.

В работе Н. Максимчук и В. Морий (2012) на примере РФ и РК рассмотрены вопросы взаимодействия и интеграции торговых площадок Московской биржи (MOEX), РТС и Казахстанской фондовой биржи KASE [8]. 
Работа М.А. Милевской (2009) посвящена исследованию интеграционных процессов развитых фондовых рынков мира за годы, начиная с 2000г. [9], где анализируются способы их объединения. Рассмотрены объединения таких мировых площадок как: NYSE (Нью-Йоркская фондовая площадка) c Euronext (европейской фондовой биржей), LSE (Лондонская фондовая биржа) с Borsa Italiana (Миланской фондовой площадкой), Nasdaq (Американская компьютерная биржа) с OMX (Шведская фондовая площадка) и пр. Выявлены автором два способа объединения - официальный (заключение между биржами ряда договоров) и неофициальный (тесное сотрудничество). Автором дополнительно выделены два способа интеграции - кооперация (альянс или союз) и слияние / поглощение.

Еще в одной работе А.А. Хрысевой (2011) проведен динамический анализ развивающихся фондовых рынков и влияния на них мирового финансового кризиса 2008 года [10]. Отмечено, что среди фондовых бирж Казахстана, России и Белоруссии KASE пострадала меньше всего и включена в S\&P/IFCG Frontie Indices, что рассматривает глобализационные процессы через диверсификацию портфеля и стратегии инвестирования.

Исследования по интеграции фондовых площадок носят описательный характер событий. Исследований и научных работ с использованием большого объема статистических данных по объемам торгов, списка и цен биржевых инструментов практически нет. К тому же интеграционные процессы стран Евразийского экономического союза (ЕАЭС), идут полным ходом. Принято Решение Высшего Евразийского экономического совета № 20, от 01.10.2019 г. «О Концепции формирования общего финансового рынка (ОФР) ЕАЭС», а научных исследований, посвященных оценке влияния интеграционных процессов, касаемых отечественного фондового рынка тоже пока нет. В данном утвержденном Решении основными направлениями формирования ОФР является «обеспечение взаимного доступ участников..., развитие инфраструктуры ОФР и пр.» [11].

В данной статье произведена попытка дать оценку вхождения Московской биржи в капитал Казахстанской фондовой биржи как одного из альтернативных путей повышения странового рейтинга Казахстана и вхождения в развивающиеся страны в условиях интеграции и формирования общего биржевого пространства ЕАЭС.

Методологическую основу составили методы познания, экономического анализа и сравнения, исследование документов и пр. материалов. В процессе исследования применялся институциональный подход. Так, при оценке странового риска использовались методики широко известных международных рейтинговых агентств MSCI и FTSE Group.

Научной и информационной базой явились научные публикации зарубежных и отечественных ученых, а также нормативноправовые акты Казахстана. Источниками данных послужили официальная информация Казахстанской фондовой биржи, Московской биржи, материалы международных рейтинговых агентств FTSE и MSCI, Национального банка Республики Казахстан, Центрального банка России, компьютерной системы Bloomberg и др.

\section{Результаты и обсуждения}

Привлекательность актива является ключевым детерминантом ликвидности [12]. Но, при отсутствии необходимого качества и количества инвесторской базы, он может сместиться на второй план. По сравнению c KASE развитой базой инвесторов может похвастаться MOEX (рисунок 1).

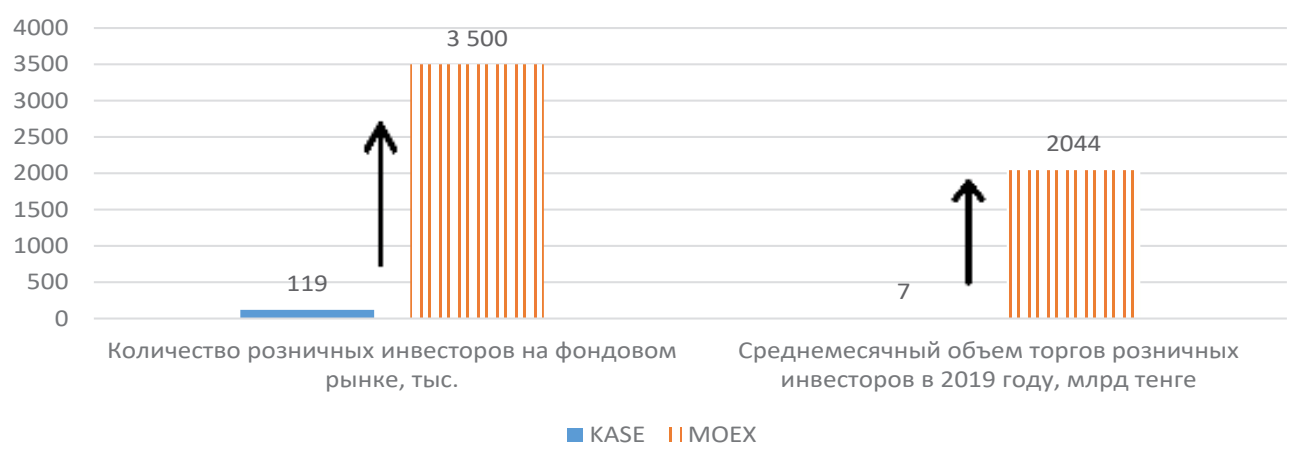

Рисунок 1 - Розничные инвесторы

Figure 1 - Retail Investors

Примечание - Источники [13, 14$]$ 
Как видно из рисунка, на МОЕХ общее количество частных инвесторов составило 3500 тыс. человек, при объеме накоплений населения свыше 5 трлн. российских рублей в ценных бумагах. Одновременно в Центральном депозитарии KASE количество лицевых счетов физических лиц составило 119 тысяч или почти в 30 раз меньше, чем аналогичный показатель в России [13].

Однако только по количеству инвесторов нельзя судить о степени их вовлеченности в биржевые торги. С января по ноябрь 2019 года объем торгов на вторичном рынке акций MOEX достиг 11 трлн рублей, а доля розничных инвесторов в данном сегменте стабильно держится выше 30\% [14]. Соответственно, население России в среднем ежемесячно заключает сделки на сумму свыше 330 млрд рублей (2 трлн тенге при биржевом курсе 6,05 тенге за рубль). В то же время среднемесячный объем торгов физических лиц на вторичном рынке акций KASE за девять месяцев 2019 года составил 6,7 млрд тенге [13]. Выходит, что население России торгует более чем в 300 раз больше, чем жители Казахстана.

Разница действительно внушительная, и она потенциально продолжит свое увеличение. Из последних рыночных трендов особенно важным является заметное снижение ключевой ставки Центрального Банка России - за последние полгода (с июня по декабрь 2019 года) она была снижена на полтора процента (рисунок 2). Вслед за ключевой ставкой коммерческие банки снизили доходности депозитов, что стало стимулом перетока накоплений населения с депозитов в ценные бумаги. Дополнительным фактором на сайте Банка России указывается «развитие цифровых технологий и сервисов удаленной идентификации, внедренных на российском финансовом рынке и предоставляющих возможность открыть брокерский счет, не выходя из дома» [14].

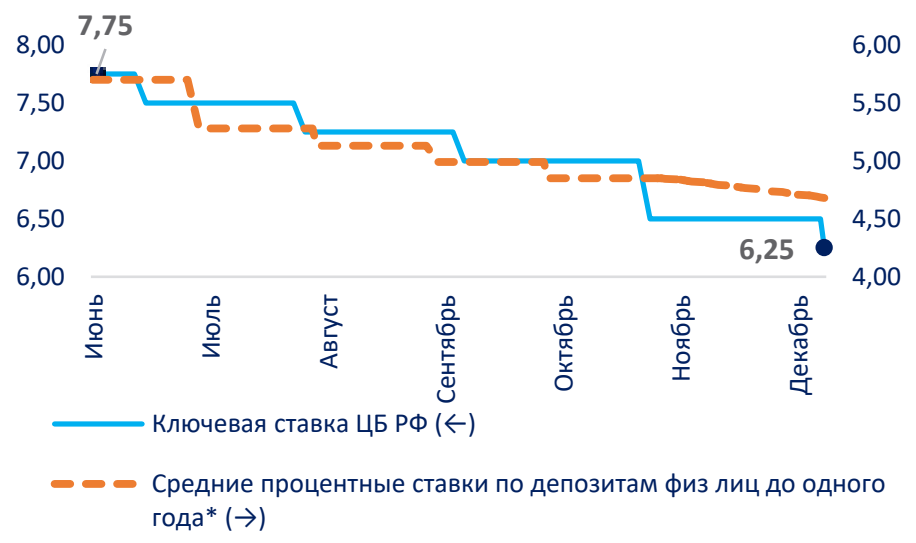

Рисунок 2 - Ключевая ставка Банка России в 2019 году и депозитная ставка БВУ, \% годовых

Figure 2 - The key rate of the Bank of Russia in 2019 and the deposit rate of STB, \% per annum

Примечание - Источники [15]

Таким образом, можно сделать вывод, что по текущему положению рынка, приток даже $1 \%$ от среднемесячного объема торгов розничных инвесторов на MOEX (20 млрд тенге) на биржевой рынок KASE приведет к увеличению объема торгов физических лиц KASE в четыре раза.

Однако для реализации потенциала притока инвесторской базы MOEX на биржевой рынок KASE необходимо включение российских брокеров в список членов KASE. В 2017 году доля нерезидентов на рынке акций составила 5,2\%, в 2018 - 10,5\% (сделки совершались преимущественно в ноябре и декабре), за три квартала 2019 года доля нерезидентов достигла $21,3 \%$. По состоянию на декабрь 2019 года в списке членов KASE числилось 23 брокера по фондовой категории, среди которых два российских - УНИВЕР Капитал (с 28.02.2017) и ООО ИК «Фридом Финанс» (с 27.02.2018).

Оценка эффекта потенциального притока инвесторской базы с Московской биржи для казахстанских компаний представлена на рисунке 3. 


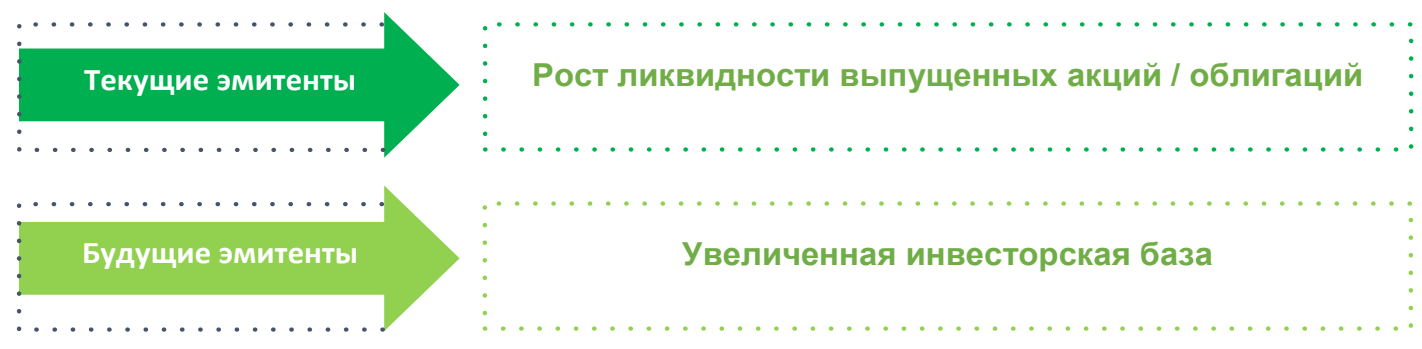

Рисунок 3 - Эффект притока инвесторской базы с Московской биржи

Figure 3 - The effect of the influx of the investor base from the Moscow Exchange

Примечание - Разработано авторами

Для действующих компаний чьи акции/облигации уже торгуются на бирже, потенциально увеличение ликвидности их ценных бумаг. Будущие же эмитенты будут обеспечены большей инвесторской базой, что позволит более эффективно размещать ценные бумаги [15].

Оценка положительного влияния роста ликвидности

Ликвидность является одним из основных атрибутов многих инвестиционных планов [16]. На рынке ценных бумаг управляющие портфелями и инвестиционные консультанты подбирают портфели в соответствии с инвестиционными горизонтами своих клиентов и ограничениями ликвидности.

Положительная оценка роста ликвидности акций является общепринятым мнением, которое объясняется рядом причин:

1. Уменьшение спрэда котировок между ценами покупки-продажи. Величину спрэда можно расценивать в качестве «упущенной» стоимости акций и капитализации компании [17].

2. Данных по оценке среднего спрэда котировок на KASE пролистингованных ценных бумаг нет. Но по правилам биржи для маркет-мейкеров устанавливают: максимальное значение спрэда - от 1 до $3 \%$, объем обязательных котировок - 2000-3000 МРП. Фактическое значение спрэда в период повышенной волатильности превышает лимит и достигает 5\%, а среднее значение спрэдов котировок акций в 2013-2018 годах, пролистингованных и на MOEX, и на Лондонской бирже (LSE) не превышал 21 базисный пункт [14].

3. Казахстанский фондовый рынок считается недооцененным из-за низкой ликвидности ценных бумаг. И чем больше участников рынка будут высказывать свои мнения по поводу цены на активы, тем выше вероятность приближения котировок акций к их справедливой стоимости.

4. Всем известно, что чем больше количество инвесторов, тем более глубже «стакан», а это позволит ограничивать манипуляции игроков и снизить риск резкой волатийности цен при заключении сделки отдельными покупателями.

5. Однако, при покупке или продаже инвесторами финансового актива большими партиями сдвигают рыночную цену в неблагоприятную для себя сторону. Чем глубже рынка, тем менее будут ощущать негативный эффект отдельные участники торгов.

6. Снижение волатильности приводит к снижению бэты-коэффициента, приводит к уменьшению стоимости капитала и росту капитализации компании. Более высокое значение бэта-коэффициента - увеличивает стоимость капитала и снижает стоимость ценных бумаг при их дисконтировании.

Потенциал роста капитализации казахстанских компаний представлен на рисунке 4.

Как мы видим из рисунка, наблюдается потенциальный эффект увеличения капитализации отечественных организаций от роста ликвидности акций.

Касательно оцуенки интереса акичий казахстанских компаний со стороны российских инвесторов

Как было отмечено выше, первостепенным фактором, объясняющим разницу в ликвидности акций различных компаний, является привлекательность самой компании. В связи с этим встает вопрос, будут ли интересны текущие публичные и потенциально публичные компании Казахстана.

В состав премиум класса MOEX вошли наиболее ликвидные 15 акций российских эмитентов, которые представляют разные секторы экономики России (рисунок 5). 


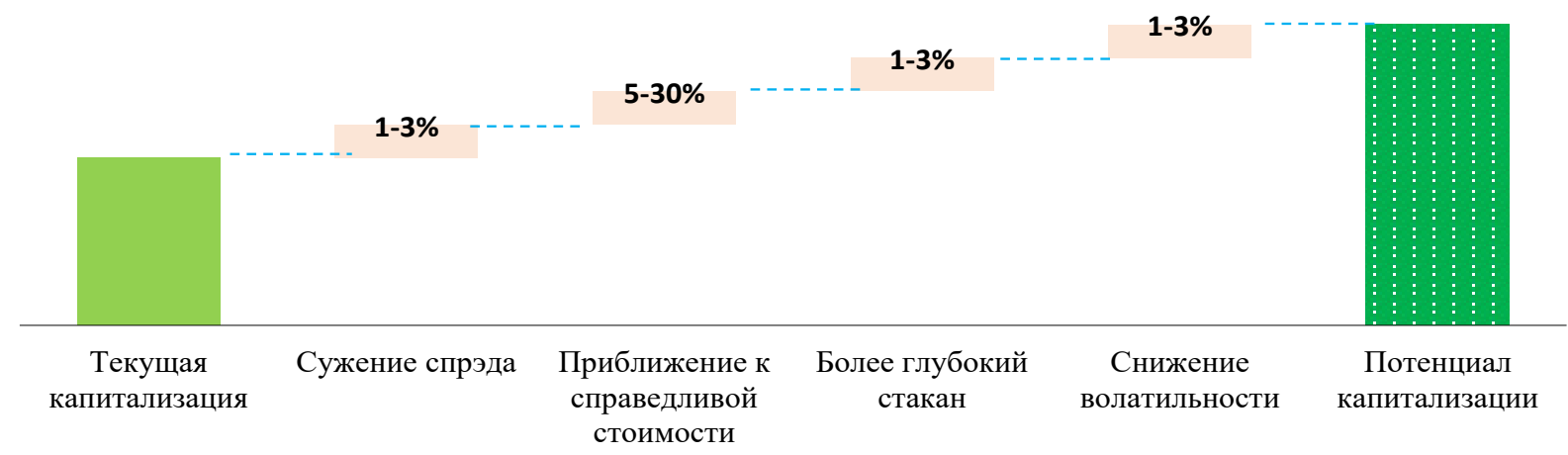

Рисунок 4 - Потенциал роста капитализации казахстанских компаний Figure 4 - Potential for growth in the capitalization of Kazakh companies

Примечание - Источники [13]

\begin{tabular}{|c|c|}
\hline Индекс голубых фишек МОЕХ & $\begin{array}{r}\text { Некоторые представители Индекса } \\
\text { KASE, приватизируемые и } \\
\text { потенциально публичные компании } \\
\text { Казахстана }\end{array}$ \\
\hline $\begin{array}{l}\text { ПАО "Газпром" } \\
\text { ПАО "ЛУКОЙЛ" } \\
\text { ПАО "НОВАТЭК" } \\
\text { ПАО "НК "Роснефть" } \\
\text { ПАО "Сургутнефтегаз" } \\
\text { ПАО "Татнефть" }\end{array}$ & НК Казмунайгаз, Казтрансойл \\
\hline ПАО Сбербанк & Народный банк Казахстана, Kaspi \\
\hline $\begin{array}{l}\text { ПАО "Северсталь" } \\
\text { ПАО "ГМК "Норильский никель" } \\
\text { ПАО "НЛМК" }\end{array}$ & KAZ Minerals, Казатомпром \\
\hline ПАО "МТС" & Казахтелеком \\
\hline $\begin{array}{l}\text { X5 Retail } \\
\text { ПАО "Магнит" }\end{array}$ & Magnum \\
\hline $\begin{array}{l}\text { Яндекс Н.В. } \\
\text { АК "АЛРОСА" (ПАО) }\end{array}$ & \\
\hline
\end{tabular}

Рисунок 5 - Представительский список индексов бирж MOEX и KASE Figure 5 - Representative list of indices of MOEX and KASE stock exchanges

Примечание - Источники $[13,14]$

Ha KASE помимо долевых торгуются и долговые ценных бумаг с привлекательной доходностью [18]. Например, осенью 2019 года Министерство финансов разместили свои казначейские обязательства под проценты, свыше 9,3\% годовых, в то время как ставка ОФЗ в зависимости от срока погашения варьировалась в пределах от 6,67 до 7,99\% годовых.

Касательно рынка в целом спрэды безрисковых кривых доходностей Казахстана и России начинаются от 5\% на краткосрочных периодах до 1 года, заканчивая $2 \%$ - на долгосрочных периодах (20 лет и выше).
Некоторые аспекты валютного риска для российских инвесторов

Валютный риск резонно можно назвать основным для международных инвесторов. Высокая доходность активов, номинированных в иностранной валюте, может быть нивелирована скачками обменных курсов валют. С начала 2019 года официальный курс пары рубль / тенге вырос на 11,4\% до 6,15 тенге за рубль - значительные потери для инвестора, который оценивает свою доходность в рублях. 


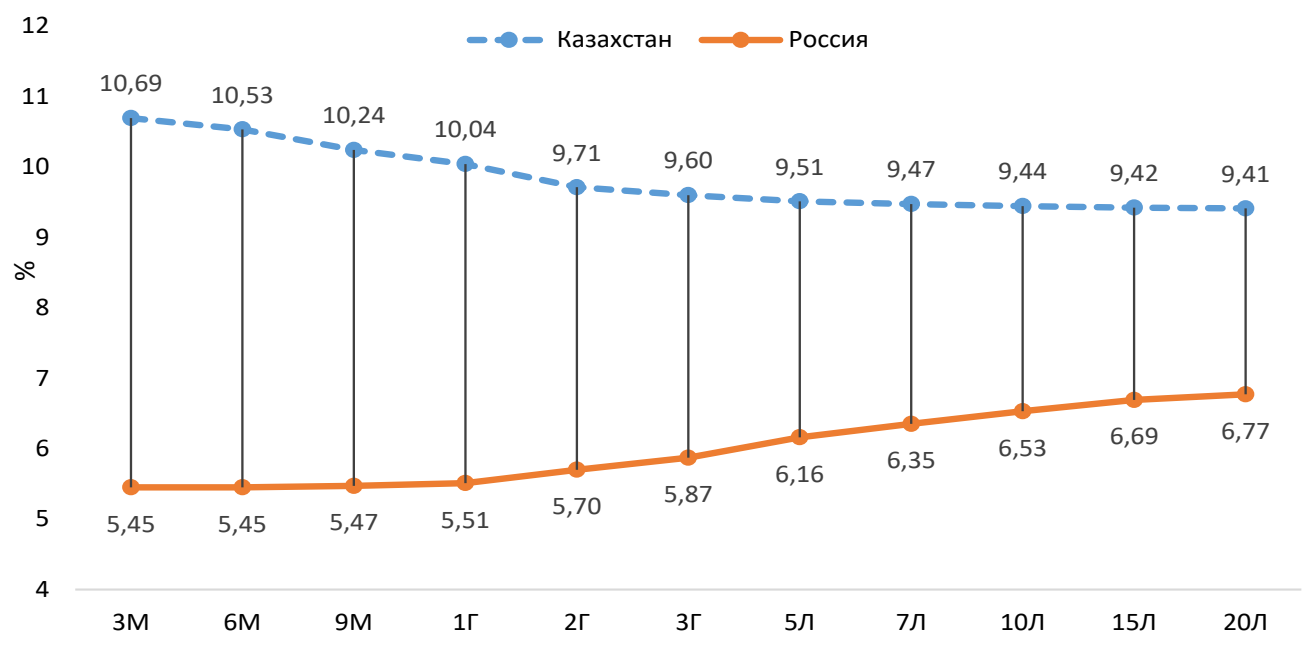

Рисунок 6 - Безрисковые кривые доходности Казахстана и России (График построен по совпадающим датам до погашения)

Figure 6 - Risk-free yield curves of Kazakhstan and Russia (The chart is built on the same dates to maturity)

Примечание - Источники [19, 20]

Однако такая динамика не является неожиданностью, поскольку есть макроэкономические предпосылки. Казахстан является перманентным нетто-импортером в торговых отношениях с Россией. Более $60 \%$ товарооборота Казахстана с Россией рассчитывается рублях. По базовым законам экономики - в долгосрочной перспективе валюта страны с дефицитом торгового баланса будет слабеть к валюте страны экспортера. Однако стоит подчеркнуть, что это касается долгосрочной перспективы, которая проходит постепенно, чего не скажешь о текущей динамике курса рубля к тенге. Тем не менее, и этому есть логичное объяснение.

Во избежание валютного арбитража кросс-курсы валют должны находиться в балансе. Отсюда должно соблюдаться равенство: USDRUB = USDKZT / RUBKZT и $\triangle$ USDRUB $=\triangle$ USDKZT - $\triangle$ RUBKZT. C момента перехода к свободно плавающему валютному режиму в Казахстане рубль стремительно стал крепнуть к тенге, отыгрывая потери предыдущих периодов и пробил отметку в 5 тенге за рубль, сохранявшуюся долгое время. При спокойном движении пары USDRUB, пара RUBKZT постепенно росла. Однако санкционное давление на Россию со стороны США ослабляло курс рубля к доллару, что отражалось в росте пары USDKZT и снижении RUBKZT. Однако с течением времени (экспертная оценка - 4 месяца) после объявления санкций, пара RUBKZT восстанавливалась. В течение всего 2019 года не приходило вестей о санкциях, а котировки нефти находились на благоприятных уровнях. Стабильное макроэкономическое положение позволило рублю в паре с долларом достичь 17-месячного пика, а в паре с тенге отыграть потери санкций и достичь нового исторического максимума.

Таким образом, зная основные драйверы курсов валют, закладывая собственные ожидания на объясняющие факторы, можно успешно регулировать валютный риск и даже увеличивать свою доходность на разнице курсов.

\section{Выводы}

На основе проведенного исследования нами получены:

- на основе мониторинга и анализа существующих методологий рассчета странового риска предложен самый популярный в качестве бэнчмарка и определения странового рейтинга - индекс MSCI, согласно которому в 2017 году Республике Казахстан. присвоен рейтинг «Frontier market»;

- выявлены ключевые цели сотрудничества и вхождения Московской биржи в капитал Казахстанской фондовой биржи;

- выявлено, что данные цели сотрудничества выгодны инвесторам и, в целом, всей экономике страны;

- проведен качественный и количественный анализ инвесторской базы Московской биржи на предмет привлекательности активов как ключевого детерминанта его ликвидности; 
- сделан вывод, что по текущему положению рынка, приток даже $1 \%$ от среднемесячного объема торгов розничных инвесторов на MOEX (20 млрд. тенге) на биржевой рынок KASE приведет к увеличению объема торгов физических лиц KASE в четыре раза;

- дана оценка положительного влияния роста ликвидности акций;

- построены по совпадающим датам до погашения графики безрисковых кривых доходности Казахстана и России;

- выявлены некоторые аспекты валютного риска для российских инвесторов и др.

Областью применения полученных результатов является казахстанский фондовый рынок.

Таким образом, дана оценка: потенциального притока инвесторской базы c Московской биржи для казахстанских компаний, положительного влияния роста ликвидности и капитализации казахстанских компаний и интереса акций казахстанских компаний со стороны российских инвесторов. В совокупности это дает некую оценку вхождения Московской биржи в капитал Казахстанской фондовой биржи.

\section{Список использованных источников}

1. Байбулекова Л.А. Мониторинг альтернативных методик определения странового риска для определения контуров казахстанского фондового рынка. Евразийский научный форум «Евразийская экономическая интеграция: становление и развитие» Central Asian Economic Rewiew. - 2018. -. №4. - C. 54-67.

2. Teles, V.; Andrade, J. (2017). Monetary policy and country risk. Applied Economics, Vol. (40), 20212028. DOI: $10.1080 / 00036840600949249$

3. Официальный сайт международного рейтингового агентства MSCI/ In assets under management are benchmarked to MSCI indexes [Электронный ресурс]/ - URL: https://www.msci. com/index-solutions (дата обращения 15.08.2021).

4. Официальный сайт международного рейтингового агентства MSCI/ MSCI Kazakhstan Index (USD) [Электронный ресурс] / - URL: https:// www.msci.com/documents/ 10199/d16d913d-caeb4598-adac-f4a4ffdab500 (дата обращения 15.08.2021).

5. MSCI announces the results of the 2021 annual market classification review. Morgan Stanley Capital International (MSCI); 2021 [Обновлено 3 мая 2021, процитировано 20 сентября 2021]. Доступно: https://www.msci.com/market-classification

6. Официальный сайт $\mathrm{AO}$ «Национальный банк Республики Казахстан» [Электронный ресурс] / - URL: (дата обращения 05.09.2021).
7. Авилкина М.А. Интеграция фондовых рынков России, Казахстана и Белоруссии в рамках единого экономического пространств: проблемы и перспективы. Вестник Полоцкого государственного университет. - 2014. - №13. - С.78-82.

8. Максимчук Н.В., Морий В.О. Глобальные тенденции в биржевом сегменте и перспективы создания интеграционного биржевого пространства стран ЕЭП. Евразийская экономическая интеграция. - 2012. - № 2. - С.25-36

9. Милевкая М.А. Международная интеграция как тенденция развития международного финансового рынка. Актуальные вопросы экономических наук. - 2009. - №8. - С.13-17.

10. Хрысева А.А. Специфика механизма инвестирования на финансовом рынке в условиях глобализации. Известия Волгоградского государственного технического университета. - 2011. №14. - С.157-163.

11. Решение Высшего Евразийского экономического совета № 20, от 1 октября 2019 года «О Концепции формирования общего финансового рынка Евразийского экономического союза» https://adilet.zan.kz/rus/docs/H19B0000020 (дата обращения 15.06.2021).

12. Beck, T., Levine, R. (2004). Stock markets, banks, and growth: Panel evidence. Journal of Banking and Finance, №28(3), 423-442. DOI : 10.1016/S03784266(02)00408-9

13. Официальный сайт АО «Казахстанская фондовая биржа» [Электронный ресурс] / - URL: https://www.kase.kz/ (дата обращения 01.10.2021).

14. Официальный сайт ПАО «Московская Биржа ММВБ-РТС» [Электронный ресурс] / URL: https://moex.com. (дата обращения 15.06.2021).

15.Байбулекова Л.А., Лухманова Г.К. Активизация фондового рынка Казахстана на фоне неэффективности его банковского сектора. Экономика. Профессия. Бизнес. - 2019. - №1. C.12-19.

16. Байбулекова Л.А. и др. Повышение надежности инфраструктуры казахстанской фондовой биржи в современных условиях. Вестник Университета Туран, 1 (85), Алматы. - 2020.- С.183187.

17. Официальный сайт ежемесячного британского журнала Euromoney [Электронный pecypc] - URL: https://www.euromoney.com (дата обращения 08.05.2021).

18. Байбулекова Л.А., Абсеметова Д.А., Тажибаева А. Конкурентоспособность фондового рынка Республики Казахстана. Materiály XIV mezinárodní vědecko - Praktická konference efektivní nástroje moderních věd Dubna. - Ekonomika. - 2018. - Volume 4. - C. 38-45.

19. Официальный сайт Центрального банка Российской Федерации. - URL: https://www.cbr.ru/ (дата обращения 01.10.2021).

20.Официальный сайт поставщика финансовой информации Bloomberg [Электронный pecypc] / - https://ru.wikipedia.org/wiki/Bloomberg (дата обращения 05.09.2021). 


\section{References}

1. Baibulekova, L.A. (2018). [Monitoring of alternative methods for determining the country risk to determine the contours of the Kazakhstani stock market]. Evrazijskij nauchnyj forum «Evrazijskaja jekonomicheskaja integracija: stanovlenie i razvitie» Central Asian Economic Reshhieshh. 4, 54-67. (In Russ.)

2. Teles, V., Andrade, J. (2017). Monetary policy and country risk. Applied Economics, Vol. (40), 2021-2028. DOI: 10.1080/00036840600949249

3. Official website of the international rating agency MSCI, (2021). In assets under management are benchmarked to MSCI indehes [Jelektronnyj resurs]. URL: $\quad$ https://shhshhshh.msci.com/indeh-solutions (data obrashhenija 15.08.2021).

4. Official website of the international rating agency MSCI, (2021). MSCI Kazakhstan Indeh (USD) [Jelektronnyj resurs]. URL: https://shhshhshh.msci. com/documents/ 10199/d16d913d-caeb-4598-adacf4a4ffdab500 (data obrashhenija 15.08.2021).

5. MSCI announces the results of the 2021 annual market classification revieshh. Morgan Stanley Capital International (MSCI); 2021 [Obnovleno 3 maja 2021, procitirovano 20 sentjabrja 2021]. Dostupno: $\quad$ https://shhshhshh.msci.com/marketclassification

6. Official website of JSC "National Bank of the Republic of Kazakhstan" (2021) [Jelektronnyj resurs]. URL: (data obrashhenija 05.09.2021).

7. Avilkina, M.A. (2014). [Integration of the stock markets of Russia, Kazakhstan and Belarus within the framework of a single economic space: problems and prospects: problemy i perspektivy]. Vestnik Polockogo gosudarstvennogo universitet. 13, 78-82. (In Russ.)

8. Maksimchuk, N.V., Morij, V.O. (2012). [ Global Trends in the Exchange Segment and Prospects for Creating an Integration Exchange Space of the CES Countries]. Evrazijskaja jekonomicheskaja integracija. 2, 25-36. (In Russ.)

9. Milevkaja, M.A. (2009). [ International integration as a trend in the development of the international financial market]. Aktual'nye voprosy jekonomicheskih nauk. 8, 13-17.

10. Hryseva, A.A. (2011). [The specifics of the investment mechanism in the financial market in the context of globalization]. Izvestija Volgogradskogo gosudarstvennogo tehnicheskogo universiteta. 14, 157163.

11. [Decision of the Supreme Eurasian Economic Council No. 20 of October 1, 2019]. O Koncepcii formirovanija obshhego finansovogo rynka Evrazijskogo jekonomicheskogo sojuza https://adilet. zan.kz/rus/docs/H19B0000020 (data obrashhenija 15.06.2021).

12. Beck, T., Levine, R. (2004). Stock markets, banks, and groshhth: Panel evidence. Journal of Banking and Finance, 28(3), 423-442. DOI : 10.1016/S03784266(02)00408-9
13. [Official website of the Joint Stock Company "Kazakhstan Stock Exchange"]. (2021). [Jelektronnyj resurs]. URL: https://shhshhshh.kase.kz/ (data obrashhenija 01.10.2021).

14. [Official website of PJSC Moscow Exchange MICEX-RTS]. (2021). [Jelektronnyj resurs]. URL: https://moeh.com. (data obrashhenija 15.06.2021).

15. Baibulekova, L.A., Lukhmanova, G.K. (2019). [Activation of the stock market of Kazakhstan against the background of the inefficiency of its banking sector]. Jekonomika. Professija. Biznes. 1, 1219. (In Russ.)

16. Baibulekova, L.A. etc. (2020). [Improving the reliability of the infrastructure of the Kazakhstan stock exchange in modern conditions]. Vestnik Universiteta Turan, Almaty. 1 (85), 183-187.

17. [Official website of the monthly British magazine Euromoney]. (2021). [Jelektronnyj resurs]. URL: https://shhshhshh.euromoney.com (data obrashhenija 08.05.2021).

18. Baibulekova, L.A., Absemetova, D.A., Tazhibayeva A. (2018). [Competitiveness of the stock market of the Republic of Kazakhstan]. Materiály HIV mezinárodní vědecko. Praktická konference efektivní nástroje moderních věd Dubna. Ekonomika. Volume 4, 38-45.

19. [Official website of the Central Bank of the Russian Federation]. (2021). URL: https://shhshhshh. cbr.ru/(data obrashhenija 01.10.2021).

20. [Official website of the provider of financial information Bloomberg] (2021). [Jelektronnyj resurs]. https://ru.shhikipedia.org/shhiki/Bloomberg (data obrashhenija 05.09.2021). 


\section{Information about the authors}

Lyailya A. Baibulekova - PhD in Economics, Professor, K. Sagadiev University of International Business, Kazakhstan,e-mail: bal0303@mail.ru, ORCID ID: https://orcid.org/0000-0002-6820-6035

* Nazym K. Zaitenova - PhD, K. Sagadiev University of International Business, Kazakhstan, e-mail: nazym beisebaeva@mail.ru, ORCID ID: https://orcid.org/0000-0001-9971-2240

Gulmira S. Sugirova - PhD in Economics, Acting Assistant Professor, Al-Farabi Kazakh National university, Kazakhstan,e-mail: gulmirasugir@gmail.com, ORCID ID: https://orcid.org/0000-0002-3888-9242

\section{Авторлар туралы мәліметтер}

Байбөлекова Л.Ә. - э.ғ.к., профессор, К. Сағадиев атындағы Халықаралық бизнес университеті, Қазақстан, e-mail: bal0303@mail.ru, ORCID ID: https://orcid.org/0000-0002-6820-6035

* Зайтенова Н.К. - Хат-хабаршы авторы, PhD, К. Сағадиев атындағы Халықаралық бизнес университеті, Қазақстан, e-mail: nazym beisebaeva@mail.ru, ORCID ID: https://orcid.org/0000-0001-9971-2240

Сүгірова Г.С. - э.ғ.к., доцент м.а., Әл-Фараби атындағы Қазақ Ұлттық университеті, Қазақстан, е-таil: gulmirasugir@gmail.com, ORCID ID: https://orcid.org/0000-0002-3888-9242

\section{Сведения об авторах}

Байбулекова Л.А. - к.э.н., профессор, Университет международного бизнеса им. К.Сагадиева, Казахстан, e-mail: bal0303@mail.ru, ORCID ID: https://orcid.org/0000-0002-6820-6035

* Зайтенова Н.К. - Корреспондирующий автор, $\mathrm{PhD}$, Университет международного бизнеса им.К. Сагадиева, Казахстан,e-mail: nazym beisebaeva@mail.ru, ORCID ID: https://orcid.org/0000-0001-9971-2240

Сугирова Г.С.-- к.э.н., и.о. доцента, Казахский национальный университет им. аль-Фараби, Казахстан, e-mail: gulmirasugir@gmail.com, ORCID ID: https://orcid.org/0000-0002-3888-9242 